\title{
"PEMBERDAYAAN KOPERASI SISWA SMK PEMBANGUNAN NASIONAL SUKOHARJO" DALAM RANGKA OPTIMALISASI POTENSI DAERAH YANG DAPAT DIGUNAKAN UNTUK MEMBANGUN KEMANDIRIAN EKONOMI
}

\author{
Irwan Christanto Edy ${ }^{1 *)}$, Shandy Marsono ${ }^{2}$, Heriyanta Budi Utama ${ }^{3}$ \\ STIE Adi Unggul Bhirawa Surakarta \\ *Email : irwan_aub@yahoo.co.id
}

\begin{abstract}
ABSTRAK
Koperasi merupakan badan usaha yang berlandaskan demokrasi ekonomi yang tujuan utamanya untuk meningkatkan kesejahteraan anggota khususnya dan masyarakat pada umumnya serta ikut membangun tatanan perekonomian nasional dalam rangka mewujudkan masyarakat adil dan makmur berlandaskan Pancasila "dan Undang-undang dasar 1945. Koperasi Sekolah merupakan "Titik Masuk Menguasai "Lingkaran Setan" Pengangguran dan Kewirausahaan (Priambodo, 2006). Koperasi sekolah sebagai penunjang program pembangunan pemerintah di sektor perekonomian, melalui program pendidikan koperasi di sekolah, menumbuhkan koperasi sekolah dan kesadaran berkoperasi di kalangan siswa, membina rasa tanggung jawab, disiplin dan juga koperasi sekolah dijadikan sebagai sarana untuk memenuhi kebutuhan siswa terutama kebutuhan peralatan sekolah. Program Pengabdian kepada Masyarakat (PKM) merupakan program kegiatan perguruan tinggi untuk meningkatkan kapabilitas lembaga/institusi/ perusahaan dalam mengatasi permasalahan di masyarakat. PKM bagi siswa SMK ini bertujuan untuk memberikan bekal pengetahuan, membangun sikap mental, memberikan ketrampilan dan pendampingan koperasi siswa. Koperasi siswa merupakan salah satu pendidikan karakter kewirausahaan. Metode yang digunakan dalam kegiatan PKM ini dengan memberikan pelatihan dan pendampingan pada siswa SMK. Dalam kegiatan PPM ini Tim pelaksana bermitra dengan SMK Pembangunan Nasional Sukoharjo Jawa Tengah. Kegiatan yang memberikan bekal pengetahuan dan ketrampilan yang dilakukan dengan (1) memberikan penyuluhan dan pelatihan tentang koperasi. Ukuran keberhasilan dari kegiatan PPM ini dapat dilihat dari : (1) tingkat pemahaman dan skill dalam berorganisasi, (2)optimalisasi koperasi siswa, (3) Kehadiran peserta kegiatan PKM ini. Temuan dari PKM ini adalah model koperasi siswa yang mampu menjadi wadah pendidikan karakter.
\end{abstract}

Kata kunci : Koperasi, Siswa, Pelatihan, Pendampingan, SMK

\section{A. Pendahuluan}

Dalam Pasal 33 ayat (1) Undang-Undang Dasar Negara Republik Indonesia Tahun 1945 ditegaskan bahwa perekonomian disusun sebagai usaha bersama berdasarkan atas asas kekeluargaan. Ketentuan tersebut sesuai dengan prinsip koperasi, oleh karena itu koperasi mendapat misi untuk berperan nyata dalam menyusun perekonomian yang berdasarkan atas asas kekeluargaan dan demokrasi ekonomi yang mengutamakan kemakmuran bersama bukan kemakmuran orang-seorang.

Koperasi merupakan badan usaha yang berlandaskan demokrasi ekonomi yang tujuan utamanya untuk meningkatkan kesejahteraan anggota khususnya dan masyarakat pada umumnya serta ikut membangun tatanan perekonomian nasional dalam rangka mewujudkan masyarakat adil dan makmur berlandaskan Pancasila dan Undang-undang dasar 1945. Dalam koperasi manfaat yang diterima anggota lebih diutamakan dari pada laba, meskipun demikian dalam pelaksanaannya diharapkan koperasi tidak mengalami kerugian.

Koperasi didirikan bertujuan untuk memperbaiki kehidupan ekonomi dan sosial anggotanya, misalnya melalui koperasi konsumsi mereka dapat meningkatkan penghasilan dan taraf hidup mereka, karena mereka akan memperoleh harga barang-barang yang murah sekaligus dapat bersosialisasi dengan anggota lain melalui organisasi koperasi. Melalui sosialisasi mereka dapat saling berbagi untuk memecahkan masalah ekonomi yang mereka hadapi begitu pula koperasi siswa yang beranggotakan 
guru, pegawai sekolah dan siswa, mereka dapat memenuhi kebutuhan ekonominya melalui koperasi yang mereka usahakan secara bersama, dikelola dan diawasi bersama untuk kesejahteraan bersama.

Koperasi sekolah adalah koperasi yang terdiri dari siswa-siswa Sekolah Dasar, Sekolah Menengah Tingkat Pertama, Sekolah Menengah Tingkat Atas, Pondok Pesantren, dan Lembaga Pendidikan lainnya yang setaraf(Suwandi, 1982:2). Koperasi sekolah sebagai penunjang program pembangunan pemerintah di sector perekonomian, melalui program pendidikan koperasi di sekolah, menumbuhkan koperasi sekolah dan kesadaran berkoperasi di kalangan siswa, membina rasa tanggung jawab, disiplin dan juga koperasi sekolah dijadikan sebagai sarana untuk memenuhi kebutuhan siswa terutama kebutuhan peralatan sekolah.

SMK Pembangunan Nasional Sukoharjo memiliki sebuah koperasi sekolah. Koperasi sekolah tersebut menjual berbagai kebutuhan siswa seperti buku tulis, alat-alat tulis, makanan kecil dan minuman. Dari hasil observasi awal, koperasi tidak mengalami kerugian yang begitu besar dan dapat dilihat dari Sisa Hasil Usaha yang diterima setiap tahunnya.

Tetapi peran serta atau partisipasi anggota belum maksimal sesuai yang diharapkan. Masih banyak anggota yang belum sepenuhnya menjadi pelanggan koperasi. Hal ini dapat dilihat dari sedikitnya siswa yang berbelanja di koperasi. Terkadang mereka lalai dalam melaksanakan tugas yang sudah menjadi tanggung jawab mereka seperti jaga piket koperasi. Partisipasi anggota pada koperasi sekolah merupakan wujud nyata kesediaan anggota untuk berperan serta dalam koperasi yaitu mengikuti kegiatan-kegiatan yang diadakan koperasi yang melibatkan dan ditujukan kepada anggota.

Anoraga dan Widiyanti (2007:111) menyatakan bahwa partisipasi anggota adalah kesediaan anggota untuk memikul kewajiban dan menjalankan hak keanggotaan secara bertanggung jawab.Partisipasi siswa merupakan salah satu bentuk keterlibatan siswa dalam pengelolaan koperasi di sekolah. Padahal partisipasi aktif siswa sebagai anggota merupakan syarat mutlak bagi kemajuan koperasi. Dengan demikian dapat kita pahami bahwa berhasil atau tidaknya suatu koperasi, tak terkecuali koperasi sekolah tergantung pada kualitas atau loyalitas diri para anggota dan pelaksanaannya.

Hasibuan (2008:95) mengungkapkan bahwa motivasi adalah pemberian daya penggerak yang menciptakan kegairahan kerja seseorang, agar mereka mau bekerja sama, bekerja efektif dan terintegrasi dengan segala daya upayanya untuk mencapai kepuasan. Anoraga dan Widiyanti (2003:15) menyebutkan bahwa anggota dikatakan memiliki motivasi berkoperasi apabila ada dorongan dan keinginan yang timbul dari dirinya untuk menjadi anggota koperasi dalam upaya memenuhi kebutuhannya.Pemberian motivasi berarti memberikan kesempatan pada anggota koperasi untuk mampu mengembangkan kemampuannya dan merupakan dorongan semaksimal mungkin anggota untuk berbuat atau berproduksi, dengan begitu kinerja anggota akan lebih baik bila dibandingkan tanpa pemberian motivasi satupun pada suatu koperasi.

\section{B. Kajian Teori tentang Koperasi}

Menurut UU No. 17 Tahun 2012 tentang perekonomian yang dimaksaud dengan koperasi adalah badan hukum yang didirikan oleh orang perseorangan atau badan hukum koperasi, dengan pemisahan kekayaan para anggotanya sebagai modal untuk menjalankan usaha, yang memenuhi aspirasi dan kebutuhan bersama di bidang ekonomi, sosial dan budaya sesuai dengan nilai dan prinsip koperasi. 
Koperasi Sekolah ialah koperasi yang didirikan oleh para siswa sebagai tempat pendidikan dan latihan berkoperasi di sekolah. Koperasi Sekolah tidak berbentuk badan hokum, tetapi mendapat pengakuan sebagai perkumpulan koperasi dari Kantor Departemen Koperasi.

Adapun pertimbangan koperasi sekolah yaitu :

1. menunjang program pembangunan pemerintah di sector perkoperasian melalui program pendidikan sekolah.

2. menumbuhkan koperasi sekolah dan kesadaran berkoperasi di kalangan siswa.

3. membina rasa tanggung jawab, disiplin, setia kawan,dan jiwa koperasi.

4. meningkatkan pengetahuan dan keterampilan berkoperasi agar berguna kelak di masyarakat.

5. membantu kebutuhan para siswa dan mengembangkan kesejahteraan siswa di dalam dan luar sekolah.

Kerja sama koperasi berlandaskan individualitas dan solidaritas. Nilai individualis tidak dikobarkan untuk tujuan kerja sama, tetapi untuk isi mengisi dan dikembangkan.

Tujuan Koperasi Sekolah

Tujuan didirikan Koperasi sekolah yaitu :

1. Memasyarakatkan koperasi melalui pendidikan ekonomi dan koperasi di sekolah.

2. Menanamkan dan mendidik kesadaran hidup bergotong-royong dan setia kawan di antara para siswa.

3. Menumbuhkan rasa tanggung jawab, disiplin, dan jiwa demokrasi pada siswa.

4. Menunjang pendidikan sekolah ke arah kegiatan-kegiatan praktis yang dapat memenuhi kebutuhan para siswa.

5. Menunjang program pembangunan pemerintah di sector perkoperasian melalui program pendidikan koperasi di sekolah.

6. Mendidik para siswa agar menjadi Warga Negara Indonesia yang berguna dan bertanggung jawab terhadap kesejahteraan masyarakat dan negara.

Jenis-Jenis Koperasi Sekolah

Berikut ini adalah jenis-jenis kopersi sekolah yaitu;

1. Koperasi Simpan Pinjam (KSP), adalah koperasi yang memiliki usaha tunggal yaitu menampung simpanan anggota dan melayani peminjaman. Anggota yang menabung (menyimpan) akan mendapatkan imbalan jasa dan bagi peminjam dikenakan jasa. Besarnya jasa bagi penabung dan peminjam ditentukan melalui rapat anggota.Dari sinilah, kegiatan usaha koperasi dapat dikatakan "dari, oleh, dan untuk anggota."

2. Koperasi Serba Usaha (KSU), adalah koperasi yang bidang usahanya bermacam-macam. Misalnya, unit usaha simpan pinjam, unit pertokoan untuk melayani kebutuhan sehari-hari anggota juga masyarakat, unit produksi, unit wartel.

3. Koperasi Konsumsiadalah koperasi yang bidang usahanya menyediakan kebutuhan sehari-hari anggota. Kebutuhan yang dimaksud misalnya kebutuhan bahan makanan, pakaian, perabot rumah tangga. 
4. Koperasi ProduksiKoperasi produksi adalah koperasi yang bidang usahanya membuat barang (memproduksi) dan menjual secara bersama-sama.Anggota koperasi ini pada umumnya sudah memiliki usaha dan melalui koperasi para anggota mendapatkan bantuan modal dan pemasaran.

\section{Ciri-ciri Koperasi Sekolah}

1. Bentuknya Badan Usaha yang tidak berbadan Hukum.

2. Anggotanya siswa-siswa sekolah tersebut.

3. Keanggotannya selama kita masih menjadi siswa.

4. Koperasi sekolah dibuka pada waktu istirahat.

5. Sebagai latihan dan praktik berkoperasi.

6. Melatih disiplin dan kerja.

7. Menyediakan perlengkapan pelajar.

8. Mendidik siswa hemat menabung.

9. Tempat menyelanggarakan ekonomi dan gotong royong.

Berikut ini beberapa peran dari koperasi sekolah.

1. Menunjang pendidikan sekolah ke arah kegiatan-kegiatan praktis guna mencapai kebutuhan ekonomis di kalangan siswa.

2. Mengembangkan rasa tanggung jawab, disiplin, setia kawan dan jiwa demokratis pada siswa.

3. Sebagai tempat memperdalam pengetahuan berkoperasi.

4. Sebagai tempat untuk melatih keterampilan berkoperasi seperti praktik pembukuan atau akuntansi, praktik administrasi, praktik tata niaga, dan lain-lain.

5. Memenuhi kebutuhan ekonomi para siswa, misalnya penyediaan alat tulis menulis, baju, seragam, makanan, dan sebagainya.

Prinsip Koperasi Sekolah

Menurut UU No. 25 tahun 1992 Pasal 5 disebutkan prinsip koperas sekolah, yaitu:

1. Keanggotaan bersifat sukarela dan terbuka

2. Pengelolaan dilakukan secara demokratis

3. Pembagian Sisa Hasil Usaha (SHU) dilakukan secara adil sebanding dengan besarnya jasa usaha masing-masing anggota (andil anggota tersebut dalam koperasi)

4. Pemberian balas jasa yang terbatas terhadap modal

5. Kemandirian

6. Pendidikan perkoprasian

7. kerjasama antar koperasi

C. Hasil dan Pembahasan

Solusi untuk mengatasi permasalahan koperasi di sekolah secara ringkas dapat digambarkan dalam alur yang terdiri dari 9 tahap tahap sebagai berikut : 


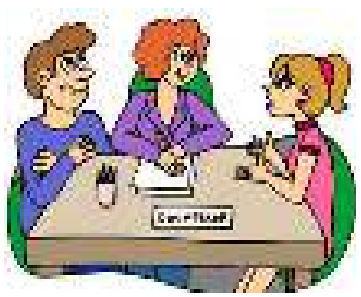

Tahap (1)

Rapat Koordinasi "Persiapan Kegiatan"

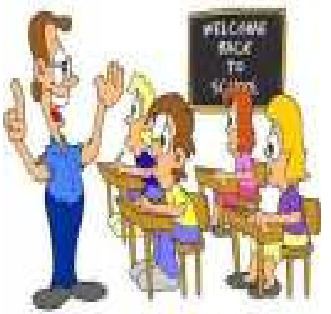

Tahap (5) Diskusi dan Sharing "Model KWU"

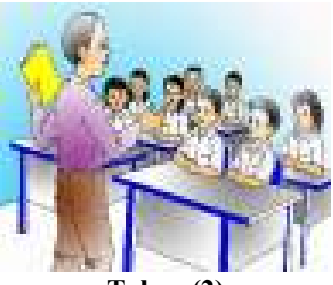

Tahap (2)

Pemilihan 25 Siswa Calon Wirausaha

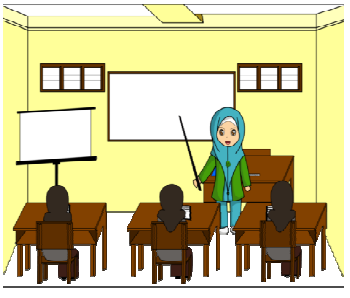

Tahap (3)

Program Penyuluhan "Kewirausahaan"

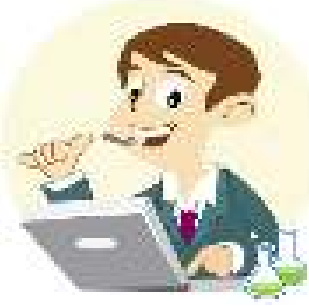

Tahap (7)

Penyusunan Laporan Kegiatan PKM

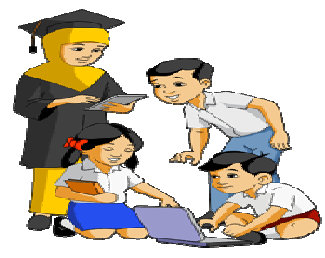

Tahap (4)

Program Penyuluhan "Studi kelayakan Bisnis"

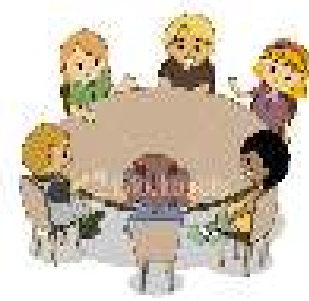

Tahap (8)

Diskusi hasil dengan Sekolah

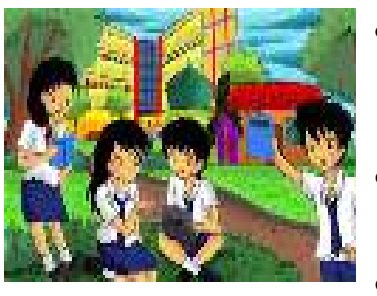

- Unit Layanan Bisnis sebagai wadah bagi siswa untuk mengembangkan kemampuan berwirausaha. Guru kurikulum kewirausahaan bertanggung jawab untuk mendampingi siswa SMK dalam berwirausaha.

- Unit Layanan Bisnis KWU khusus pada produk kuliner yang memenuhi kebutuhan masyarakat.

- Luaran kegiatan PPM ini adalah Laporan Akhir, Jurnal

Tahap (9) Unit Bisnis KWU

Secara umum solusi dari permasalahan mitra dapat dilakukan hal hal sebagai berikut :

1. Dalam rangka meningkatkan pengetahuan tentang koperasi dan bisnis pada siswa, dapat dilakukan dengan kegiatan memberikan penyuluhan/ceramah/ kuliah tentang manajemen koeprasi. Dengan kegiatan ini siswa diharapkan memahami tentang bisnis dan prakteknya.

2. Dalam rangka meningkatkan pengetahuan dan ketrampilan dalam mengawali usaha/bisnis pada siswa, dapat dilakukan dengan kegiatan memberikan pelatihan atau workshop tentang manajemen teknis membuat koperasi. Dengan kegiatan ini diharapkan siswa mampu rencana pendirian koperasi siswa 
3. Dalam rangka, meningkatkan motivasi, minat, dan sikap untuk koperasi bagi siswa dapat dilakukan dengan kegiatan mengundang tokoh pendiri koperasi yang telah sukses membangun koperasi.

4. Dalam rangka meningkatkan tingkat partisipasi sekolah dengan membentuk Forum Group Diskusi (FGD) yang melihatkan kepala sekolah, guru, siswa, pakar koperasi membuat model penerapan koperasi siswa yang potensial dapat dikembangkan di sekolah beserta instrument yang diperlukan.

5. Meningkatkan ketrampilan berkoperasi siswa dapat dilakukan dengan melakukan pendampingan dan menyediakan wadah yang berupa unit usaha yang produktif seperti penjualan alat tulis, fotocopi dan sebagainya

\section{Bentuk Kegiatan}

Dengan permasalahan yang ada, maka tim pelaksana Pengabdian pada Masyarakat STIEAUB Surakarta menawarkan penyelesaian dalam bentuk memberikan pelatihan dan pendampingan tentang koperasi siswa. Adapun materi pelatihan yang akan diberikan kepada siswa SMK Pembangunan Nasional Sukoharjo adalah:

1. Pelatihan tentang perkoperasian

2. Pelatihan tentang membangun koperasi

3. Pelatihan studi kelayakan bisnis pada koperasi

4. Diskusi dan Sharing

\section{E. Sasaran Kegiatan}

Sasaran dari kegiatan tim pengabdian pada masyarakat STIE “AUB” Surakarta ini untuk siswa SMK Pembangunan Nasional Sukoharjo ini, supaya mereka mempunyai pengetahuan dan ketrampilan, motivasi, minat dan semangat dalam berkoperasi.

\section{Kesimpulan}

Koperasi sekolah adalah koperasi yang didirikan di sekolah yang anggota-anggotanya terdiri dari siswa. Mereka dilatih untuk mengembangkan ketrampilannya dan bersikap tanggung jawab. Landasan pokok koperasi sekolah yaitu: UUD 1945 pasal 33 ayat 1. Modal koperasi sekolah di dapat dari modal sendiri dan modal dari pihak luar. Lapangan Usaha Koperasi sekolah berada dalam lingkungan sekolah yang usahanya meliputi sektor ekonomi yang dapat memenuhi kebutuhan para siswa sekolah. Dengan adanya koperasi sekolah, siswa mudah mendapatkan keperluan sekolah dengan harga yang terjangkau 


\section{DAFTAR PUSTAKA}

Arifin Sitio dan Tamba Halomoan, Koperasi: Teori dan Praktik, Erlangga, Jakarta, 2001.

G. Kartasapoetra, et.all., Koperasi Indonesia Yang Berdasarkan Pancasila dan UUD 1945, PT Rineka Cipta, Jakarta, 1991.

Edilius, Sudarsono. Koperasi dalam Teori \& Praktik. cet. 5. Jakarta : Rineka Cipta. 2010.

Firdaus, M. dan Agus Edhi. Perkoperasian : Sejarah, Teori \& Praktek. cet.2. Bogor : Ghalia Indonesia. 2004

Mulyo, J. H. (2007). Revitalisasi Ekonomi Kerakyatan Melalui Pemberdayaan Gerakan Koperasi (http:// io.ppi.- jepang.org/article)

Rahadja, Sutantya. Hukum Koperasi Indonesia. Ed.1. Cet.3. Jakarta : PT Raja Grafindo Persada. 2005.

Soedarsono Hadisapoetra, Pokok-Pokok Pikiran Pengembangan Koperasi di Indonesia, CV. Sapta Caraka, Jakarta, 1986.

Sukidjo. (2008). Membangun Citra Koperasi. Jurnal Ekonomi \& Pendidikan. 5(2), 193- 203.

Undang-Undang No. 25 Tahun 1992 Tentang Perkoperasian.

Priambodo. (2006). Koperasi Sekolah: Titik Masuk Menguasai "Lingkaran Setan" Pengangguran dan Kewirausahaan. Jurnal Infokop. No.28 Tahun XXII. 2006 Jakarta: Dekopin

Peraturan Menteri Koperasi dan Usaha Kecil dan Menengah Republik Indonesia Nomor 15 Tahun 2015 tentang Usaha Simpan Pinjam oleh Koperasi 